\title{
Incidence of the Finger Defect in Golden Jubilee Medical Center: A 2-Year Retrospective Study
}

\author{
${ }^{1}$ Pokpong Amornvit, ${ }^{2}$ Sahana Bajracharya, ${ }^{3}$ Dinesh Rokaya, ${ }^{4}$ Konrawee Keawcharoen \\ ${ }^{5}$ Somchart Raucharernporn, ${ }^{6} \mathrm{Nimit}$ Thongpulsawasdi
}

\begin{abstract}
The study was done to see the incidence of the finger defect and to develop a nomenclature system with the help of questionnaire, clinical examination, and radiographs of the finger defects obtained in two standard planes.The results of this study demonstrate that finger injuries were common males than females and the defect was more common in the right hand and in middle fingers. Amputation was more common at the level of distal phalanges.
\end{abstract}

Keywords: Finger injuries, Machinery, Car accident.

How to cite this article: Amornvit P, Bajracharya S, Rokaya D, Keawcharoen K, Raucharernporn S, Thongpulsawasdi N. Incidence of the Finger Defect in Golden Jubilee Medical Center: A 2-Year Retrospective Study. World J Dent 2014; 5(3):143-146.

\section{Source of support: Nil}

Conflict of interest: None

\section{INTRODUCTION}

Fingers are among the most mobile and active parts of the body. Fingers are injured from the daily activities like working, eating, playing and other activities. ${ }^{1}$ The congenital anomalies involving finger or the finger injury creates anxious of problems as well as long-term functional disability and esthetic. ${ }^{1,2}$

It is important to understand the incidence and causes of finger defect. This will help the clinician for the diagnosis and treatment planning. The amount of tissue remaining, condition of the bone and the number of fingers involved have to be considered when choosing suitable treatment option. ${ }^{3}$ Several microsurgical techniques, such as toe-foot-

${ }^{1}$ Maxillofacial Prosthodontist, ${ }^{2,3}$ Resident

${ }^{4,5}$ Oral and Maxillofacial Surgeon, ${ }^{6}$ Orthopedic Surgeon

1-3 Maxillofacial Prosthetic Clinic, Department of Prosthodontics Faculty of Dentistry, Mahidol University, Bangkok, Thailand

${ }^{4,5}$ Department of Maxillofacial Surgery, Golden Jubilee Medical Center, Mahidol University, Bangkok, Thailand

${ }^{6}$ Department of Orthopedic Surgery, Golden Jubilee Medical Center, Mahidol University, Bangkok, Thailand

Corresponding Author: Pokpong Amornvit, Maxillofacial Prosthodontist, Maxillofacial Prosthetic Clinic, Department of Prosthodontics, Faculty of Dentistry, Mahidol University 6 Yothi Street, Bangkok 10400, Thailand, Phone: +66-891616260 e-mail: pokpong_am@yahoo.com transfer, lengthening procedure and the use of osteocutaneous flap may offer opportunities to reconstruct the lost or missing phalanges. ${ }^{4}$ The use of bone-anchored implant retained silicone finger prosthesis represents an alternative technique. Bone anchoring method is used since 1994 for the rehabilitation of finger defects. ${ }^{5}$

The aim of this study is to study the incidence of the finger defect in Golden Jubilee Medical Center, Mahidol University from 2012 to 2014 by developing a nomenclature system developed by maxillofacial prosthetic and orthopedic department with the help of history, clinical examination and radiographs of the remaining stump of the finger and digit.

\section{MATERIALS AND METHODS}

This retrospective study of the patient's record of the finger defect between 2012 to 2014 at the Golden Jubilee Medical Center. This study involved total 10 patients and 16 treated fingers. The study protocol was approved by the Committee in University Hospital. The demographic data were collected include the sex, causes of the defect, involved hand, finger and digital bone as shown in Tables 1 and 2. The radiographs of the finger defects were obtained in two standard planes in each patient (Figs 1A and B). The mode of treatments received was also recorded.

The proposed Mahidol University (MU) system consists of 1 alphabetic and 2 numeric symbols. Each hand is composed of carpel, metacarpal and the digits with phalanges. The alphabetic symbol indicates the right (R) or left (L) side.
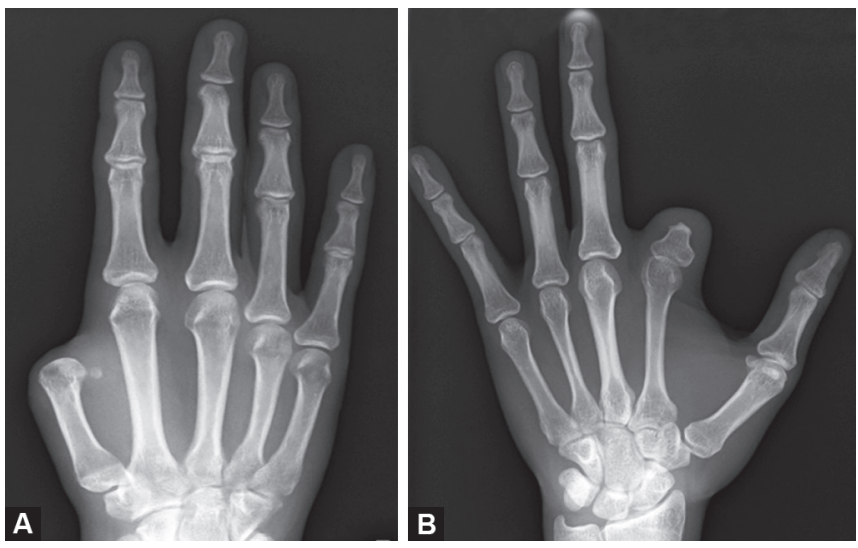

Figs 1A and B: Hand wrist X-rays of some cases: $(A)$ case 1 , (B) case 10 
The 5 digits in each hand (thumb, index, middle, ring and little finger) are denoted by the numbers as elaborated in Table 3. Each digit has three bones, i.e. proximal, middle and distal phalanx except the thumb which is comprised of only proximal and distal phalanx. The remaining of each phalanx bone in each digit is further indicated with the numerical symbols (Table 4). During the evaluation of the

Table 1: Demographic data

\begin{tabular}{lll}
\hline & $\begin{array}{l}\text { Number of } \\
\text { patients }\end{array}$ & $\begin{array}{l}\text { Percentage } \\
(\%)\end{array}$ \\
\hline Sex & 6 & 60 \\
Male & 4 & 40 \\
Female & & \\
Causes & 1 & 10 \\
Congenital & 9 & 90 \\
Acquired & 4 & 44.4 \\
Machinery & 1 & 11.11 \\
Car accident & 1 & 11.11 \\
Explosion & 1 & 11.11 \\
Assault & 2 & 22.22 \\
Others & 10 & 100 \\
\hline Total & & \\
\hline
\end{tabular}

Table 2: Site prevalence of the hand injuries

\begin{tabular}{lll}
\hline & $\begin{array}{l}\text { Number of } \\
\text { patients }\end{array}$ & $\begin{array}{l}\text { Percentage } \\
(\%)\end{array}$ \\
\hline $\begin{array}{l}\text { Involved hand side } \\
\quad \text { Right (R) }\end{array}$ & 7 & 70 \\
$\quad$ Left (L) & 3 & 30 \\
$\begin{array}{l}\text { Involved fingers } \\
\quad \text { Thumb }\end{array}$ & & \\
$\quad$ Index & 3 & 16.66 \\
$\quad$ Middle & 4 & 22.22 \\
Ring & 5 & 27.77 \\
$\quad$ Little & 4 & 22.22 \\
Involved/missing & 2 & 11.11 \\
phalange bone & & \\
Distal & & \\
Distal, middle & 6 & 35.29 \\
Distal, middle and & 4 & 23.35 \\
proximal & 5 & 29.41 \\
Distal and proximal & & \\
Metacarpal & 2 & 11.17 \\
\hline
\end{tabular}

cases, the partial remaining of the phalanx bone were also observed. These incomplete or partial remaining of phalanx bone is denoted by the alphabet ' $I$ '.

\section{RESULTS}

This study showed the incidence of finger defect was greater in male $(60 \%)$ and the common acquired causes of the finger defect were machinery (44.44\%), car accident (11.11\%), explosion (11.11\%), assault (11.11\%), others $(22.22 \%)$ as shown in the Table 3.

The finger defect was present more on right side (70\%) and the involved fingers were as thumb (16.66\%), index finger $(22.22 \%)$, middle finger $(27.77 \%)$, ring finger $(22.22 \%)$, little finger $(11.11 \%)$ as shown in the Table 4 . The involved digits were as distal phalange (35.29\%), distal and middle (23.35\%), distal, middle and proximal (29.41\%), and, distal and proximal (11.17\%). The diagnosis according to the MU system was described in the Table 4.

\section{DISCUSSION}

In this study, the higher incidence of finger defect in male may be related to the occupation and the activities. Normally, right hand side is dominant during function and work therefore, the defect was observed more on right hand side of males. In female patients, the mishaps occurred during domestic activities for instance cutting and chopping action therefore, left hand side was mostly affected.

The type of the finger defect (involved finger, number and level of amputations) results in the compromise in the specific type of the function. The common functions of the fingers are as follows: thumb is used for writing, grasping, holding; index finger is used for pressing and grasping; middle fingers isused for writing, grasping and holding compared to ring and little finger. Regarding the impact on function, the effect from the distal amputation are minimal than the proximal levels. This also affects the patient's motivation toward restoration.

The cause of the finger defect is also related with the resultant anatomy of the defect. The finger defect that results from sharp object or burn are not much deformed compared

Table 3: Abbreviations used in the study

\begin{tabular}{|c|c|c|c|c|c|c|c|}
\hline Hand side & $\begin{array}{l}\text { Alphabetical } \\
\text { demarcation }\end{array}$ & Digits & $\begin{array}{l}\text { Numerical } \\
\text { demarcation }\end{array}$ & Digital bones & $\begin{array}{l}\text { Numerical } \\
\text { demarcation }\end{array}$ & $\begin{array}{l}\text { Removal of } \\
\text { stump }\end{array}$ & $\begin{array}{l}\text { Alphabetical } \\
\text { demarcation }\end{array}$ \\
\hline Right & $\mathrm{R}$ & Thumb & 1 & Metacarpal & 0 & Complete & N/A \\
\hline \multirow[t]{4}{*}{ Left } & $\mathrm{L}$ & Index & 2 & $\begin{array}{l}\text { Proximal } \\
\text { phalanx }\end{array}$ & 1 & Incomplete & 1 \\
\hline & & Middle & 3 & $\begin{array}{l}\text { Middle } \\
\text { phalanx }\end{array}$ & 2 & & \\
\hline & & Ring & 4 & $\begin{array}{l}\text { Distal } \\
\text { phalanx }\end{array}$ & 3 & & \\
\hline & & Little & 5 & & & & \\
\hline
\end{tabular}


Incidence of the Finger Defect in Golden Jubilee Medical Center: A 2-Year Retrospective Study

Table 4: Diagnosis of the cases with Mahidol university (MU) system

\begin{tabular}{|c|c|c|c|c|c|}
\hline Case no. & $\begin{array}{l}\text { Involved } \\
\text { hand side }\end{array}$ & Involved finger & $\begin{array}{l}\text { Involved/missing } \\
\text { phalanx }\end{array}$ & $\begin{array}{l}\text { Remaining phalanx/ } \\
\text { metacarpal }\end{array}$ & $\begin{array}{l}\text { Diagnosis (MU) } \\
\text { system }\end{array}$ \\
\hline 1 & Right (R) & Thumb (1) & Distal, proximal & Metacarpal (0) & R10 \\
\hline 2 & Right (R) & Index (2) & $\begin{array}{l}\text { Distal, middle, } \\
\text { proximal }\end{array}$ & Metacarpal (0) & $\mathrm{R} 20$ \\
\hline 3 & Right (R) & $\begin{array}{l}\text { Index (2) } \\
\text { Middle (3) } \\
\text { Ring (4) }\end{array}$ & $\begin{array}{l}\text { Distal, middle } \\
\text { Distal, middle } \\
\text { Distal }\end{array}$ & $\begin{array}{l}\text { Proximal (1) } \\
\text { Proximal (1) } \\
\text { Middle (2) }\end{array}$ & $\begin{array}{l}\text { R21 } \\
\text { R31 } \\
\text { R42 }\end{array}$ \\
\hline 4 & Right (R) & $\begin{array}{l}\text { Thumb (1) } \\
\text { Middle (3) }\end{array}$ & $\begin{array}{l}\text { Distal } \\
\text { Distal, middle }\end{array}$ & $\begin{array}{l}\text { Metacarpal (0) } \\
\text { Proximal (1) }\end{array}$ & $\begin{array}{l}\text { R11 } \\
\text { R31 }\end{array}$ \\
\hline 5 & Right (R) & $\begin{array}{l}\text { Index (2) } \\
\text { Middle (3) } \\
\text { Ring (4) }\end{array}$ & $\begin{array}{l}\text { Distal } \\
\text { Distal } \\
\text { Distal, middle }\end{array}$ & $\begin{array}{l}\text { Middle (2) } \\
\text { Middle (2) } \\
\text { Proximal (1) }\end{array}$ & $\begin{array}{l}\text { R22 } \\
\text { R32 } \\
\text { R41 }\end{array}$ \\
\hline 6 & Right (R) & Thumb (1) & Distal, proximal & Metacarpal (0) & R10 \\
\hline 7 & Right (R) & $\begin{array}{l}\text { Middle (3) } \\
\text { Ring (4) } \\
\text { Little (5) }\end{array}$ & $\begin{array}{l}\text { Distal, middle, } \\
\text { proximal } \\
\text { Distal, middle, } \\
\text { proximal } \\
\text { Distal, middle, } \\
\text { proximal }\end{array}$ & $\begin{array}{l}\text { Metacarpal (0) } \\
\text { Metacarpal (0) } \\
\text { Metacarpal (0) }\end{array}$ & $\begin{array}{l}\text { R30 } \\
\text { R40 } \\
\text { R50 }\end{array}$ \\
\hline 8 & Left (L) & Little (5) & Distal & Middle (2) & L52 \\
\hline 9 & Left (L) & Thumb (1) & Distal & Proximal (1) & L11 \\
\hline 10 & Left (L) & $\begin{array}{l}\text { Index (2) } \\
\text { Middle (3) } \\
\text { Ring (4) }\end{array}$ & $\begin{array}{l}\text { Distal, middle and } \\
\text { partial of proximal } \\
\text { Distal, middle } \\
\text { Proximal, } \\
\text { distal, middle }\end{array}$ & $\begin{array}{l}\text { Partial of proximal } \\
\text { Partial of proximal }\end{array}$ & $\begin{array}{l}\text { L21(I) } \\
\text { L31 } \\
\text { L42 }\end{array}$ \\
\hline
\end{tabular}

to the defects due to an accident and outside activities. The accident and outside activities often results is crushing of the finger bone and results in deformed remaining stump which is difficult to restore.

Regarding the treatment of finger defect, mostly, the surgical rehabilitation does not result the best esthetic and causes the disability in the donor site, ${ }^{6}$ therefore, prosthetic rehabilitation is preferred. The vacuum or implant retained are two options for the prosthetic rehabilitation which is decided depending upon the level of amputation, extent of the defect and structures preserved on the injured finger or hand. Treatment of the finger defect depends on the remaining stump of the amputated finger which should be minimally $1.5 \mathrm{~cm}$ in length for the conventional friction fit silicone prostheses. ${ }^{7}$ The shorter stumps may cause the problem of instability of the prostheses. Therefore, the role of implant becomes important which also help some level of tactile sensation. The quality of the life after the finger prosthesis is increased.

Regarding the surgical techniques, one-stage technique for the implant placement in implant retained finger prosthesis is safe, reliable and efficient in metacarpal and phalangeal bone if primary stability is optimal. ${ }^{8}$ Finite element analysis (FEA) has been used to study the effects of various shapes of dental implants on distribution of stresses generated in the surrounding bone and to determine an optimal thread shape for better stress distribution. The non-uniform stress pattern at bone and might induce biomechanical overloading failures in implant and bone. ${ }^{9,10}$

The limitation of the current study is the less number of the patients. This study only included the patients who refused for the surgical rehabilitation and referred for the prosthetic rehabilitation after the surgical amputation.

\section{CONCLUSION}

Finger injuries were common in males than females and the defect was more common in the right hands and in middle fingers. Amputation was more common at the level of distal phalanges. Prosthetic replacement using finger prosthesis helped to improve the quality of the life of the patients.

\section{REFERENCES}

1. Doraiswamy NV, Biag H. Isolated finger injuries in childrenincidence and aetiology. Injury Int J Care Injured 2000;31(8): 571-573.

2. McKinstry RE. Fundamentals of facial prosthetics. Arlington: ABI Professional Publications; 1995. p. 181-192.

3. Aydin C, Karakoca S, Yilmaz H. Implant-retained digital prostheses with custom-designed attachments: a clinical report. J Prost Dent 2007;97(4):191-195.

4. Doppen P, Solomons M, Kritzinger S. Osseointegrated finger prostheses. J Hand Surg Eur 2009;34(1):29-34. 
5. Lundborg G, Branemark PI, Rosen B. Osseointegrated thumb prostheses: a concept for fixation of digit prosthetic devices. J Hand Surg Am 1996;21(2):216-221.

6. Waljee JF, Chung KC. Toe to hand transfer: evolving indications and relevant outcomes. J Hand Surg 2013;38(7):1431-1434.

7. Pereira BP, Kour AL, Leow EL, Pho RWH. Benefits and use of digital prostheses. J Hand Surg Am 1996;21(2):222-228.

8. Amornvit P, Rokaya D, Keawcharoen K, Raucharernporn S, Thongpulsawasdi N. One- vs two-stage technique for implant placement in finger prosthesis. J Clin Diagn Res 2013;7(9): 1956-1958.

9. Rangert B, Krogh PHJ, Langer B, Roekel NV. Bending overload and implant fracture: a retrospective clinical analysis. Int J Oral Maxillofac Implants 1995;10(3):326-334.

10. Amornvit P, Rokaya D, Keawcharoen K, Thongpulsawasdi N. Stress distribution in implant retained finger prosthesis: a finite element study. J Clin Diagn Res 2013;7(12): 2851-2854 